\title{
Regulatory Protein E2, Human Papillomavirus Type 18
}

National Cancer Institute

\section{Source}

National Cancer Institute. Regulatory Protein E2, Human Papillomavirus Type 18. NCI

Thesaurus. Code C17499.

Regulatory protein E2 (365 aa, $42 \mathrm{kDa}$ ) is encoded by the human papillomavirus type 18 E2 gene. This protein plays a role in both transcription and replication of viral genes. 